\title{
Missed Indicator
}

National Cancer Institute

\section{Source}

National Cancer Institute. Missed Indicator. NCI Thesaurus. Code C93596.

Specifies whether a planned or preestablished event or activity did not occur. 